8

\title{
Prenatal diagnosis and management of congenital diaphragmatic hernia
}

David Basurto ${ }^{\text {a }}$, Francesca Maria Russo ${ }^{\text {a, b }}$, Lennart Van der Veeken $^{\mathrm{a}, \mathrm{b}}$, Johannes Van der Merwe ${ }^{\mathrm{a}, \mathrm{b}}$, Stuart Hooper ${ }^{c}$, Alexandra Benachi ${ }^{\mathrm{d}, \mathrm{g}}$, Felix De Bie ${ }^{\mathrm{a}}$, Olga Gomez ${ }^{\text {e, Jan Deprest }}{ }^{\mathrm{a}, \mathrm{b}, \mathrm{f}, \mathrm{g}, \text { * }}$

${ }^{a}$ Academic Department of Development and Regeneration, Cluster Woman and Child, Biomedical Sciences, KU Leuven, Belgium

${ }^{\mathrm{b}}$ Clinical Department of Obstetrics \& Gynaecology, KU Leuven, Leuven, Belgium

${ }^{\mathrm{c}}$ The Ritchie Centre, Hudson Institute of Medical Research and Department of Obstetrics and Gynaecology, Monash University, Melbourne, Victoria, Australia

d Obstetrics and Gynaecology Department, Centre de Référence Maladie Rare: Hernie de Coupole Diaphragmatique, Hôpital Antoine Béclère, Université Paris Sud, AP-HP, Clamart, France

${ }^{\text {e }}$ BCNatal, Barcelona Center for Maternal-Fetal and Neonatal Medicine (Hospital Clínic and Hospital Sant Joan de Deu), Fetal I+D Fetal Medicine Research Center, Institut Clinic de Ginecologia, Obstetricia I Neonatologia, IDIBAPS, CIBER-ER, University of Barcelona, Spain

${ }^{\mathrm{f}}$ Institute for Women's Health, University College London, London, UK

${ }^{g}$ European Reference Network on Rare and Inherited Congenital Anomalies "ERNICA"

Keywords:

Congenital diaphragmatic hernia

Prenatal prediction

Prenatal therapy

Sildenafil

Pulmonary hypoplasia

\begin{abstract}
A B S T R A C T
Congenital diaphragmatic hernia is characterized by failed closure of the diaphragm, thereby allowing abdominal viscera to herniate into the thoracic cavity and subsequently interfering with normal lung development. At birth, pulmonary hypoplasia leads to respiratory insufficiency and persistent pulmonary hypertension (PHT), that is lethal in up to $32 \%$ of patients. In isolated cases, the outcome may be predicted prenatally by medical imaging and advanced genetic testing. In those fetuses with a predicted poor outcome, fetoscopic endoluminal tracheal occlusion may be offered. This procedure is currently being evaluated in a global randomized clinical trial (www.TOTALtrial. eu). We are currently investigating alternative strategies
\end{abstract}

* Corresponding author. Herestraat 49, 3000 Leuven, Belgium.

E-mail address: jan.deprest@uzleuven.be (J. Deprest). 
including transplacental sildenafil administration to reduce the occurrence of persistent PHT.

(C) 2018 Published by Elsevier Ltd.

\section{Introduction}

Congenital diaphragmatic hernia $(\mathrm{CDH})$ is a rare condition (prevalence: $1-4 / 10,000$ pregnancies; ORPHA: 2140) [1]. The defect typically is posterolateral (Bochdalek; $70 \%$ ); rarer forms are anterior (Morgagni; $\sim 27 \%$ ) or central ( 2\%). Bochdalek hernia is usually left sided CDH (LCDH; $85 \%$ ), whereas right-sided $\mathrm{CDH}(\mathrm{RCDH} ; 13 \%)$ or bilateral $(2 \%)$ are rare [2]. From embryonic life, abdominal organs herniate into the thorax, interfering with lung development. This leads to pulmonary hypoplasia characterized by fewer and less mature airway branches and pulmonary vessels with small cross-

Table 1

Prenatal predictors of survival and/or morbidity in $\mathrm{CDH}$.

\begin{tabular}{|c|c|c|}
\hline \multicolumn{3}{|l|}{ Prenatal Predictors of survival/morbidity } \\
\hline Center & Predictor & Imaging method \\
\hline \multicolumn{3}{|l|}{ Lung } \\
\hline $\begin{array}{l}\text { Osaka (Japan), } 1990 \text { [15] } \\
\text { San Francisco (USA), } 1996 \text { [12] } \\
\text { Mainz (Germany), } 1999 \text { [81] } \\
\text { Paris (France), 2004 [18] } \\
\text { Leuven (Belgium); London (UK); San Francisco (USA); } \\
\quad \text { Paris, Lille, Strasbourg (France); Barcelona (Spain); } \\
\text { Rotterdam, Nijmegen (The Netherlands); Tel Has } \\
\text { homer (Israel), } 2007 \text { [14] }\end{array}$ & $\begin{array}{l}\text { Lung to Thorax Transverse Area Ratio } \\
\text { Lung to Head Ratio (LHR) } \\
\text { Lung Diameter tothoracic Circumference ratio } \\
\text { Lung Volume } \\
\text { Observed to Expected LHR (O/E LHR) }\end{array}$ & Ultrasound \\
\hline Miami (USA), 2013 [16] & Quantitative Lung Index & \\
\hline Philadelphia (USA), 2000 [82] & Total Fetal Lung Volume (TFLV) & MRI \\
\hline $\begin{array}{l}\text { Brussels (Belgium); Lille, Paris, Nantes, Lyon, Bordeaux, } \\
\text { Grenoble, Rouen (France), } 2001 \text { [21] }\end{array}$ & O/E TFLV & \\
\hline \multicolumn{3}{|l|}{ Liver } \\
\hline San Francisco (USA), 1998 [28] & Liver Herniation & Ultrasound \\
\hline Houston (USA), 2015 [30] & Liver to Thorax Ratio (LiTR) & \\
\hline Tochigi-Ken (Japan), 2001 [83] & Lung to Liver Signal Intensity Ratio & MRI \\
\hline Leuven (Belgium); Lille (France), 2008 [31] & LiTR & \\
\hline Houston (USA), 2012 [29] & Percentage Liver Herniation (-\%LH) & \\
\hline \multicolumn{3}{|l|}{ Stomach } \\
\hline Seattle (USA), 1992 [32], & Stomach Position & Ultrasound \\
\hline Osaka, Kyushu (Japan), 2011 [34] & Stomach Herniation & \\
\hline Leuven (Belgium), 2015 [84] & Stomach Volume & MRI \\
\hline \multicolumn{3}{|l|}{ Vascular } \\
\hline Rotterdam (The Netherlands), 1997 [85] & Flow Velocity Waveform & Ultrasound \\
\hline Auckland (New Zeeland), 1998 [86] & Pulmonary Artery (PA) Resistance Index (RI) & \\
\hline Nagasaki (Japan), 1998 [87] & PA Pulsatility Index (PI) & \\
\hline Osaka (Japan) 2003 [43] & PA Acceleration Time/Ejection Time Ratio & \\
\hline Paris (France), 2004 [88] & PA Power Doppler (PD) Mapping & \\
\hline Toronto, Canada, 2006 [45] & PA Diameter $(\varnothing)$ & \\
\hline Paris (France), 2006 [46] & 3D PD Vascularization Flow Index (VFI) & \\
\hline Barcelona (Spain); Leuven (Belgium), 2010 [89] & Fractional Moving Blood Volume & \\
\hline \multirow[t]{2}{*}{ Cincinnati (USA), 2010 [90] } & $\varnothing \mathrm{PA} /$ Aorta & MRI \\
\hline & Mc Goon Index & \\
\hline
\end{tabular}


sectional area, structural remodeling and altered vasoreactivity [3]. At birth, this results in ventilatory insufficiency and pulmonary hypertension (PHT), which leads to neonatal death in approximately $30 \%$ of cases despite neonatal care in specialized high-volume tertiary centers with standardized protocols [4]. Survivors may suffer from chronic lung disease, persistent PHT, gastroesophageal reflux, feeding and growth problems, neurocognitive delay, hearing loss, thoracic deformations, and hernia recurrence [5]. In two thirds, the diagnosis is made by the second trimester during prenatal screening ultrasound (US) [6]. This should initiate referral to a tertiary center with experience in the perinatal management of CDH. The purpose is to rule out associated anomalies (up to $40 \%$ ) and individualize prognosis [1] by genetic testing and advanced imaging. Only after having had that information, parents can choose between expectant management with prenatal referral for elective delivery, termination of pregnancy, or, in selected patients, fetal intervention. Before that, no severity statements should be made because of potential discrepancy between initial and eventual assessment [7].

\section{Genetic testing}

Genetic testing is mandatory for accurate counseling, future pregnancies, and eligibility for prenatal therapy. A genetic etiology is found in $\leq 35 \%$ by conventional karyotyping [8]; an additional $9 \%$ of them have clinically relevant copy number variants identifiable by array comparative genomic hybridization [9], and more recently, we identified a genetic cause by targeted resequencing in $10 \%$ of archived samples. In case of associated structural defects, the search for recognized syndromes is recommended [10]. A detailed list of genetic findings associated with CDH can be found elsewhere [11].

\section{Prenatal imaging}

Imaging is dedicated to characterize associated anomalies and making a personalized prognosis (Table 1). For details on how imaging can be best done in a standardized way, we refer to a paper from the European Reference Network "ERNICA" [11].

\section{Predicting outcome by lung size}

The measurement of pulmonary size is the most logical approach to assess hypoplasia and subsequently to predict neonatal outcome. The lung-to-head ratio (LHR) is the contralateral lung size measured at the level of the 4-chamber view and divided by the head circumference [12]. The lung area is most accurately and reproducible measured by tracing [13]. However, the lungs and head do not grow at the same pace. To correct for this, LHR is better expressed as a percentage of what is expected in a normal gestational age match (O/E-LHR; calculator available at www.totaltrial.eu) [14] (Fig. 1). Other 2D methods to assess lung size are less validated and hence will not be further discussed [15-17] (Table 1).

Lung volume estimated by 3-dimensional US also correlates with neonatal outcome, yet no better than O/E-LHR $[18,19]$. The contralateral lung size may also not be measurable, and there is operator and hardware variability [20]. Magnetic resonance imaging (MRI) is the reference technique for (lung) volume estimation [21]. Further, MRI is not limited by maternal habitus, fetal position, or amniotic fluid volume [22]. In analogy to the O/E-LHR, absolute bilateral volumes are converted to a percentage of what is expected in a normal fetus ([observed-to-expected total lung volume]; O/E-TLV). The matched control can be chosen according to gestation age yet matching on body volume increases accuracy, especially when out of the normal range or uncertain dates $[21,23,24]$. Whether O/E TFLV better predicts outcome than O/E LHR remains controversial [25-27].

\section{Liver position}

Liver herniation into the thorax compromises outcome [28]. On US, liver position is usually expressed as a binary variable "up" (intrathoracic) or "down" (intra-abdominal). Quantification of liver herniation may be more sensitive to predict outcome [29-31]. We are aware of three methods for the quantification of liver herniation. With MRI, we [31] proposed to measure the ratio of liver to the total chest volume (liver herniation-to-thoracic volume ratio = MRI-LiTR), whereas Lazar et al. [29] 
A
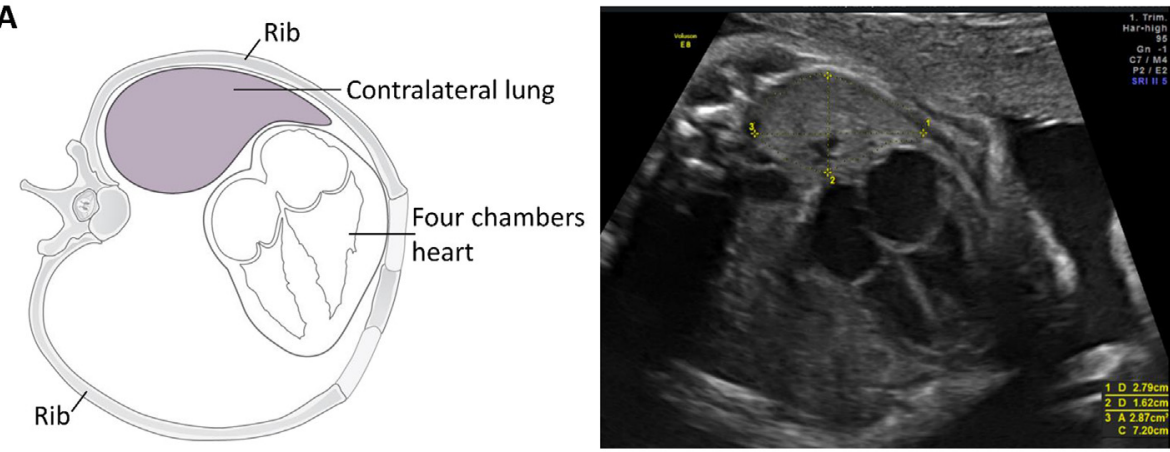

B
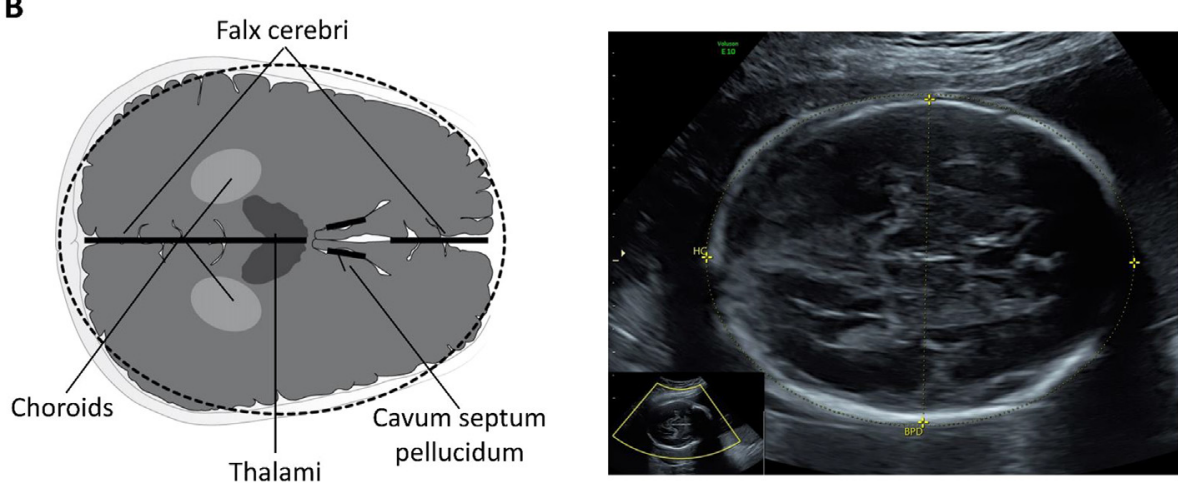

Fig. 1. Schematic drawings (left) and ultrasound images (right) of relevant sections for the calculation of the O/E LHR. A: The area of the contralateral lung is measured on the four-chamber view, with the lung close to the probe; B: Standard plane for the measurement of the head circumference. Drawings: Myrthe Boymans; reproduced with permission of the UZ Leuven.

calculated the percentage of liver that is into the fetal chest (MRI-\%Liver herniation). Britto et al. [30] described the liver-to-thoracic area ratio (US-LiTR) by 2D US, measured on the standard 4-chamber view (Table 1).

\section{Stomach position}

Stomach position as visible on US was suggested as a prognostic indicator already in 1992 [32]. Although initially a binary variable [33], Kitano suggested to grade the degree of herniation (4 steps) on coronal sections of the thorax [34]. More recently, Cordier et al. introduced a 4-step grading system using rather the standard 4-chamber views, hence facilitating its reproducibility [35]. Stomach position correlates with neonatal mortality; whether it is truly an independent predictor remains unproven, as none of the studies conducted an upfront power analysis [34-38] (Table 2). It is easier to determine the stomach position rather than quantify liver herniation, as the stomach is anechoic and the liver echogenicity is close to or identical to that of the lung [20].

\section{Pulmonary hypertension}

PHT is a major contributor to postnatal mortality [39]. PHT is believed to have a morphological and functional basis, which leads to increased pulmonary vascular resistance because of less and smaller pulmonary artery branches along with altered vasoreactivity. Persistent PHT results in right ventricular dysfunction eventually leading to right cardiac failure [40]. Although many prenatal prognostic indicators may correlate to PHT early in neonatal life, we could not demonstrate an adequate correlation with persistent PHT [41], which is the clinically relevant endpoint, as it correlates with mortality and 
Table 2

Studies reporting the value of stomach position and prediction of survival in isolated congenital diaphragmatic hernia cases managed expectantly.

\begin{tabular}{|c|c|c|c|c|}
\hline Imaging & Study & $(n)$ & Stomach grading system & Significance \\
\hline \multirow[t]{8}{*}{ Ultrasound } & Metkus et al., 1996 [12] & 55 & $\begin{array}{l}\text { Intra-thoracic } \\
\text { Intra-abdominal }\end{array}$ & $\begin{array}{l}\text { N.S. - study } \\
\text { underpowered }\end{array}$ \\
\hline & Dommergues et al., 1996 [33] & 76 & $\begin{array}{l}\text { Intra-thoracic } \\
\text { Intra-abdominal }\end{array}$ & $\mathrm{P}=.008$ \\
\hline & Laudy et al., 2003 [91] & 26 & $\begin{array}{l}\text { Intra-thoracic } \\
\text { Intra-abdominal }\end{array}$ & $\begin{array}{l}\text { N.S. - study } \\
\text { underpowered }\end{array}$ \\
\hline & Datin-Dorriere et al., 2008 [92] & 66 & $\begin{array}{l}\text { Intra-thoracic } \\
\text { Intra-abdominal }\end{array}$ & $\mathrm{P}=.043 \sim$ \\
\hline & Kitano et al., 2011 [34] + & 109 & $\begin{array}{l}\text { Coronal plane, stomach in relation to } \\
\text { the right/left thoracic plane. }(0,1,2,3)\end{array}$ & $\mathrm{P}=.014 \sim$ \\
\hline & Cordier et al., 2015 [35] & 114 & $\begin{array}{l}\text { 4-chamber view, stomach in relation } \\
\text { to the heart and AV valves. }(1,2,3,4)\end{array}$ & $\mathrm{P}=.010 \sim$ \\
\hline & Basta et al., 2016 [38] & 90 & $\begin{array}{l}\text { 4-chamber view, stomach in relation } \\
\text { to the heart }(1,2,3,4)\end{array}$ & $\mathrm{P}=<.001$ \\
\hline & Sananes et al., 2016 [36] $\approx$ & 77 & $\begin{array}{l}\text { Kitano } \\
\text { Cordier }\end{array}$ & $\begin{array}{l}\mathrm{P}=.002 \sim \\
\mathrm{P}=.018 \sim\end{array}$ \\
\hline \multirow[t]{2}{*}{ MRI } & Schaible et al., 2012 [25] & 76 & $\begin{array}{l}\text { Intra-thoracic } \\
\text { Intra-abdominal }\end{array}$ & N.S \\
\hline & Victoria et al., 2012 [37] & 85 & $\begin{array}{l}\text { Intra-thoracic/Intra-abdominal } \\
\text { 4-chamber view, stomach in relation } \\
\text { to the heart }(1,2,3,4)\end{array}$ & $\begin{array}{l}\mathrm{P}=.002 \diamond \\
\text { N.S } \\
\text { N.S }\end{array}$ \\
\hline
\end{tabular}

Abbreviations: AV, atrio-ventricular.

$\diamond$ Univariate analysis; Multivariate analysis; $\diamond$ Bivariate analysis; $\approx$ Survival until 6 months; +Intact discharge: defined as discharge without major morbidities (need for respiratory support, tube feeding, parenteral nutrition or vasodilators).

long-term morbidity [42]. The logical approach to assess lung vascularization is by direct measurement, which has been attempted by a variety of techniques. To the best of our knowledge, these measurements are not easy to reproduce, and their added predictive value remains uncertain as shown in a recent meta-analysis [41,43-49] (Table 1 ).

\section{Practical severity stratification}

The consortium currently conducting a clinical trial on fetal therapy for LCDH stratifies fetuses on the basis of O/E-LHR combined with liver position as documented on US [11]. On the basis of the expected outcome, earlier, we proposed to discriminate extreme, severe, moderate, and mild forms of pulmonary hypoplasia [14]. In LCDH, an O/E-LHR under $25 \%$ is defined as severe and an O/E-LHR 25-34.9\% (irrespective of the liver position) or 35-44.9\% with liver up as moderate. Conversely, when the latter occurs without liver herniation, or when O/E-LHR $>45 \%$, CHD is considered mild. In retrospect, referring to a condition with $40-50 \%$ mortality and $50-60 \%$ morbidity as "moderate" is semantically misleading [14]. We also acknowledge that the current prediction algorithm can be improved by using other (combinations of) parameters, yet before implementing that widely, appropriately powered studies with standardized neonatal management need to be conducted.

\section{Right-sided congenital diaphragmatic hernia}

Whether RCDH is a more severe condition and a separate entity with different outcomes and treatment response than LCDH remains a matter of controversy [50-53]. From a prenatal perspective, we documented an overall survival of 53\%, which is lower than that for LCDH [54]. In that study, the O/E-LHR correlated with survival: when under $45 \%$, survival was $17 \%$ in expectantly managed cases [54], a finding in line with that reported in our earlier multicenter study [14]. Because a $>80 \%$ mortality in LCDH correlates with an O/E-LHR $<25 \%$, and in RCDH with $<45 \%$, it is tempting to assume RCDH is a more severe 
condition. However, the anatomy of the right and left lungs is different, and on 2D ultrasound, one may not be truly measuring the same in case of LCDH or RCDH. As RCDH is rare, it will be very difficult to demonstrate with sufficient power correlations between O/E-LHR or other types of lung size measurements with mortality, let be morbidity. Additionally, liver herniation is not discriminative in RCDH, as it is nearly always present. Eventually, one may need different algorithms for this condition [50].

\section{Fetal therapy for CDH}

The ability to prenatally identify a future nonsurvivor prompts the question for an intervention that can reverse this natural course. The current clinical strategy to promote lung growth in severe cases is by percutaneous fetoscopic endoluminal tracheal occlusion (FETO) [55]. Clinical observations that fetuses with laryngeal atresia have larger lungs inspired animal experiments, which demonstrated that TO reverses experimental pulmonary hypoplasia [56,57]. Airway obstruction prevents egress of lung fluid, thereby increasing airway pressure, activating stretch receptors, and inducing proliferation. Under experimental conditions, sustained TO markedly reduced type II-pneumocyte counts and subsequently surfactant expression. This was prevented by in utero release of the occlusion ("plug-unplug sequence") and, to some extent, prenatal steroid administration [58,59]. The plug-unplug strategy was clinically translated into a percutaneous procedure with a low risk for serious maternal morbidity [60].

\section{Fetoscopic balloon insertion}

FETO is performed under sono-endoscopic guidance and local anesthesia (Fig. 2). We earlier described the technique in detail [61]. Immobilization and pain relief are obtained by fetal drug

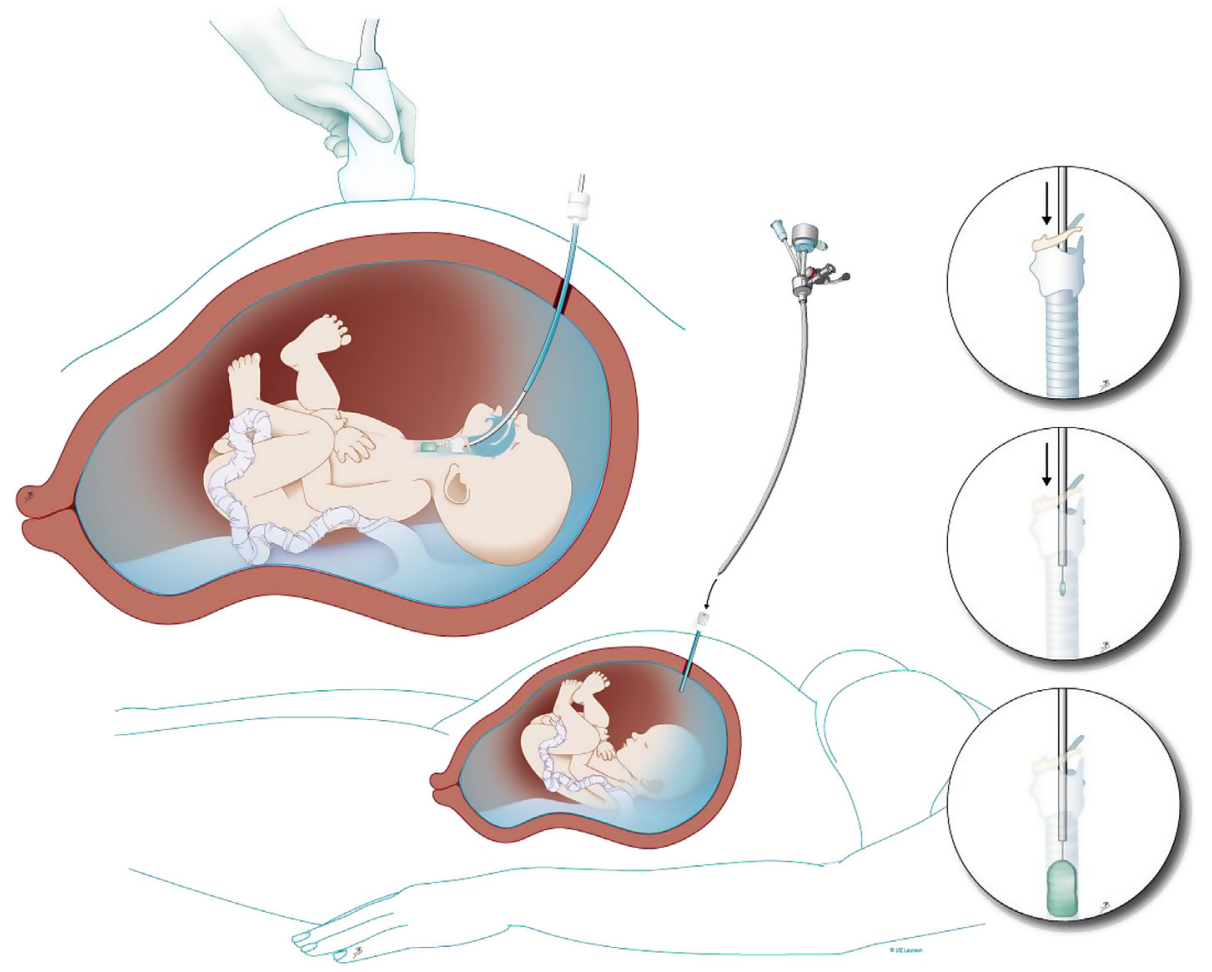

Fig. 2. Schematic drawing of percutaneous fetoscopic endoluminal tracheal occlusion. Inset: a detachable balloon, normally used for endovascular occlusion, is positioned in the trachea. Reproduced with permission from UZ Leuven, Leuven, Belgium. Drawing Myrthe Boymans. 
administration. A thin-walled flexible cannula is inserted avoiding the placenta and aiming to or above the fetal nose tip. A $1.3 \mathrm{~mm}$ fetoscope housed within a slightly curved $3.3 \mathrm{~mm}$ sheath (Karl Storz, Tuttlingen, Germany) is advanced into the trachea until the carina is visualized. A detachable balloon (Goldbal2, Balt, Montmorency, France) is positioned between the vocal cords and carina with a purpose-designed delivery catheter (Baltacci-BDPE-100; Balt). The balloon can be visualized on US as an anechoic structure. The median duration of FETO is $10 \mathrm{~min}$; longer operation times are associated with higher premature rupture of membrane (PROM) rates [62].

\section{Reestablishment of airway patency}

Clinical data suggest that prenatal balloon removal increases survival and reduces morbidity $[63,64]$. Leaving the balloon in place until delivery also creates the challenge of emergency removal at birth [65]. Prenatal removal also allows the patient to return to the institution where she would normally deliver. On the basis of animal experiments, we schedule reversal at 34 weeks, which can be done by fetoscopy, ultrasound-guided puncture, tracheoscopic removal on placental circulation, or postnatal puncture. With regard to 302 balloon removals, two thirds were by fetoscopy, $21 \%$ by puncture, $10 \%$ on placental circulation, and $1 \%$ ex utero. The modality chosen is probably a matter of surgeon preference. After puncture, the balloon is typically expelled, probably because of the spontaneous outflow of fluid from the lungs during fetal breathing. In our experience, balloon removal was done nonelective in $28 \%$. The only neonatal deaths due to balloon removal difficulties occurred when delivery took place in an unprepared setting or inexperienced center [65].

\section{Outcomes of FETO}

We already reported outcomes of more than 200 interventions. In comparison to historical controls of similar severity, FETO increased survival from $24 \%$ to $49 \%$ in severe LCDH (O/E-LHR <25\%) and seemed to improve early respiratory morbidity $[64,66]$. In RCDH with an O/E-LHR $<45 \%$, FETO increased survival from $17 \%$ to $42 \%$ [54]. In survivors, fetal tracheomegaly has been documented but does not seem to have a clinical impact apart from a barking cough, which decreases with time $[67,68]$. Adverse tracheal side effects from FETO are rare and typically occur in case of a very early occlusion and at the time of emergency balloon removal (Table 3). Our initial experience and that of others suggest benefit, as shown in a meta-analysis. Because most think that there is still equipoise, we designed a randomized clinical trial (RCT) "Tracheal-Occlusion-To-Accelerate-Lung-growth" (www.TOTALtrial.eu) in fetuses with LCDH and severe yet also moderate lung hypoplasia (NCT01240057/NCT00763737) [69]. In severe cases, balloon insertion is at 27-30 weeks. That is slightly later than initially because we aimed to decrease delivery $<32$ weeks, which adversely impacts survival [66]. In moderate cases not earlier considered eligible for fetal therapy [55], we occlude at 30-32 weeks, which still induces some lung growth [70]. In that study, we choose oxygen dependency as an additional outcome parameter. Postnatal management is standardized along the EuroCDH-consortium guidelines [71]. Recruitment in the moderate TOTAL-trial exceeds already more than $85 \%$ of the sample size. The trial arm for severe $\mathrm{CDH}$ started later, yet the first interim analysis was done in October 2017. We acknowledge that both trials started far too late because of several reasons $[72,73]$ and that the path toward the TOTAL-trial has been particularly difficult as demonstrated in the timeline (Fig. 3).

\section{Future experimental solutions}

Whatever the outcome of the TOTAL-trial, FETO is an invasive procedure with increased risk for preterm delivery and preterm rupture of membranes [66]. In addition, because of its technical complexity, FETO cannot be universally implemented. Finally, maximum post-FETO survival in severe cases is $\sim 50 \%$ and does not seem to solve persistent PHT [64]. For these reasons, alternative, less invasive, preferentially medical therapies are part of the current agenda of many research groups. For the sake of space, we highlight only one that is closest to clinical application. Sildenafil is a selective inhibitor of phosphodiesterase-5 (PDE5), which degrades cyclic guanosine monophosphate (cGMP). PDE5 acts as a key regulator of the perinatal pulmonary circulation [74]. Sildenafil is already used 
Table 3

Experience with FETO and reported complications.

\begin{tabular}{|c|c|c|c|c|c|c|c|c|}
\hline \multicolumn{9}{|c|}{ Summary of FETO series complications } \\
\hline Study & $\mathrm{N}$ & $\begin{array}{l}\text { GA at } \\
\text { FETO wk } \\
\text { (range) }\end{array}$ & $\mathrm{Ma}$ & ternal Fetal Complications & $\begin{array}{l}\text { Mean } \\
\text { GA at } \\
\text { delivery }\end{array}$ & $\begin{array}{l}\text { Preterm } \\
\text { birth } \\
<32 \text { wk }\end{array}$ & $\begin{array}{l}\text { PPROM } \\
<34 \text { wk }\end{array}$ & $\begin{array}{l}\text { Emergency } \\
\text { balloon } \\
\text { removal }\end{array}$ \\
\hline Deprest et al., 2004 [60] & 21 & $\begin{array}{l}26 \\
(25-33)\end{array}$ & $\begin{array}{l}M \\
F\end{array}$ & $\begin{array}{l}\text { No } \\
1(4.7) \text { Right bronchus laceration, } \\
\text { reinsertion one week later }\end{array}$ & 34 & $5(23.8)$ & $9(42.8)$ & $11(52.3)$ \\
\hline Kohl et al., 2006 [93] & 8 & $\begin{array}{l}30.6 \\
(29-32.4)\end{array}$ & $\begin{array}{l}M \\
F\end{array}$ & $\begin{array}{l}\text { No } \\
\text { No }\end{array}$ & 33.9 & $0(0)$ & NA & $2(25)$ \\
\hline Jani et al., 2009 [66] & 210 & $\begin{array}{l}27.1 \\
(23-33.3)\end{array}$ & $\begin{array}{l}\mathrm{M} \\
\mathrm{F}\end{array}$ & $\begin{array}{l}\text { No } \\
\text { 4(1.9) Tracheal lacerations, } \\
4(1.9) \text { IUFD ( } 1 \text { bradycardia/ } \\
3 \text { unknown), 2(0.9) TOP, } 10(4.7) \\
\text { deaths due to balloon removal } \\
\text { difficulties elsewhere }\end{array}$ & 35.3 & $36(17.4)$ & NA & 109(51.9) \\
\hline Peralta et al., 2011 [63] & 8 & $\begin{array}{l}26.8 \\
(26-29)\end{array}$ & $\begin{array}{l}M \\
F\end{array}$ & $\begin{array}{l}\text { No } \\
\text { No }\end{array}$ & 37 & $0(0)$ & $5(62.5)$ & No \\
\hline Ruano et al., 2011 [94] & 17 & NA & M & $\begin{array}{l}\text { 1(5.8) Hemoperitoneum } \\
\text { managed expectantly } \\
1(5.8) \text { Placental abruption; } \\
1(5.8) \text { balloon was in the } \\
\text { right bronchus could not be } \\
\text { retrieved and the fetus died }\end{array}$ & 35.6 & $3(17.6)$ & $6(35.2)$ & $4(25)$ \\
\hline Ruano et al., 2012 [95] & 20 & NA & $\begin{array}{l}M \\
F\end{array}$ & $\begin{array}{l}\text { 1(5) Chorioamnionitis } \\
\text { No }\end{array}$ & 35.6 & $3(15)$ & NA & $5(25)$ \\
\hline Cannie et al., 2013 [96] & 31 & $\begin{array}{l}28.6 \\
(25.3-30.7)\end{array}$ & $\begin{array}{l}\mathrm{M} \\
\mathrm{F}\end{array}$ & $\begin{array}{l}\text { 1(3.2) Hemoperitoneum } \\
\text { No }\end{array}$ & 34.7 & NA & NA & NA \\
\hline Ruano et al., 2013 [97] & 8 & 23.7 (NA) & $\begin{array}{l}\mathrm{M} \\
\mathrm{F}\end{array}$ & $\begin{array}{l}\text { No } \\
2(25) \text { tracheomegaly } \\
1 \text { trachea not accessible, and the } \\
\text { fetus died }\end{array}$ & 33.5 & $2(25)$ & $3(37.5)$ & NA \\
\hline Persico et al., 2017 [98] & 21 & $\begin{array}{l}28.1 \\
(26-31.1)\end{array}$ & $\begin{array}{l}M \\
F\end{array}$ & $\begin{array}{l}\text { No } \\
\text { NA }\end{array}$ & 34.7 & $2(9.5)$ & $10(47.6)$ & $10(47.6)$ \\
\hline Belfort et al., 2017 [99] & 11 & $\begin{array}{l}27.9 \\
(25.7-29)\end{array}$ & $\begin{array}{l}\mathrm{M} \\
\mathrm{F}\end{array}$ & $\begin{array}{l}\text { No } \\
1(9.1) \text { Chorioamniotic separation }\end{array}$ & 35.3 & $1(9.1)$ & $2(18.8)$ & $2(18.8)$ \\
\hline
\end{tabular}

Abbreviations: N, number of cases; GA, gestational age; wk, weeks; PPROM, preterm pre-labour rupture of membranes; M, maternal; F, fetal.

clinically and well tolerated by babies with CDH affected by PHT [75]. In addition to having a vasodilatory effect, sildenafil promotes pulmonary angiogenesis and inhibits pulmonary artery remodeling [76]. This was first demonstrated by Thebaud [77]. We later confirmed in a rabbit model that transplacental sildenafil leads to normal vascular wall thickness, peripheral muscularization, normal number of fifth or higher order generation of vessels, and normal Doppler flow. Sildenafil also improved airway morphology and postnatal lung mechanics. We applied and received orphan designation for this drug for the prevention of PHT in CDH from the European Medical Agency. Sildenafil has already been clinically administered in randomized controlled trials in women with preeclampsia and oligohydramnios $[78,79]$. Both trials could not identify any safety issues. In the STRIDER trial, sildenafil was given for fetal growth restriction. This trial is currently suspended because of potential harm by an increased incidence of persistent PHT and a nonsignificant trend for increased neonatal death in one out of three centers [80]. These findings still need to be confirmed because they are in contrast with those of the other two STRIDER studies (including more than 120 patients treated with sildenafil) and of other studies on antenatal sildenafil administration. Even if this would be confirmed for growth restriction, such association with PHT may not persist when the drug is given to fetuses with pulmonary hypoplasia, as in $\mathrm{CDH}$. Sildenafil has been shown in animal models to have a different effect on lung development in normal and hypoplastic lungs; in normally developed lungs, it was associated with impaired vascular branching. This suggests that the effects of sildenafil on fetal lungs are dependent on the fetal condition. Additionally, in $\mathrm{CDH}$, the drug would be given to prevent a condition 

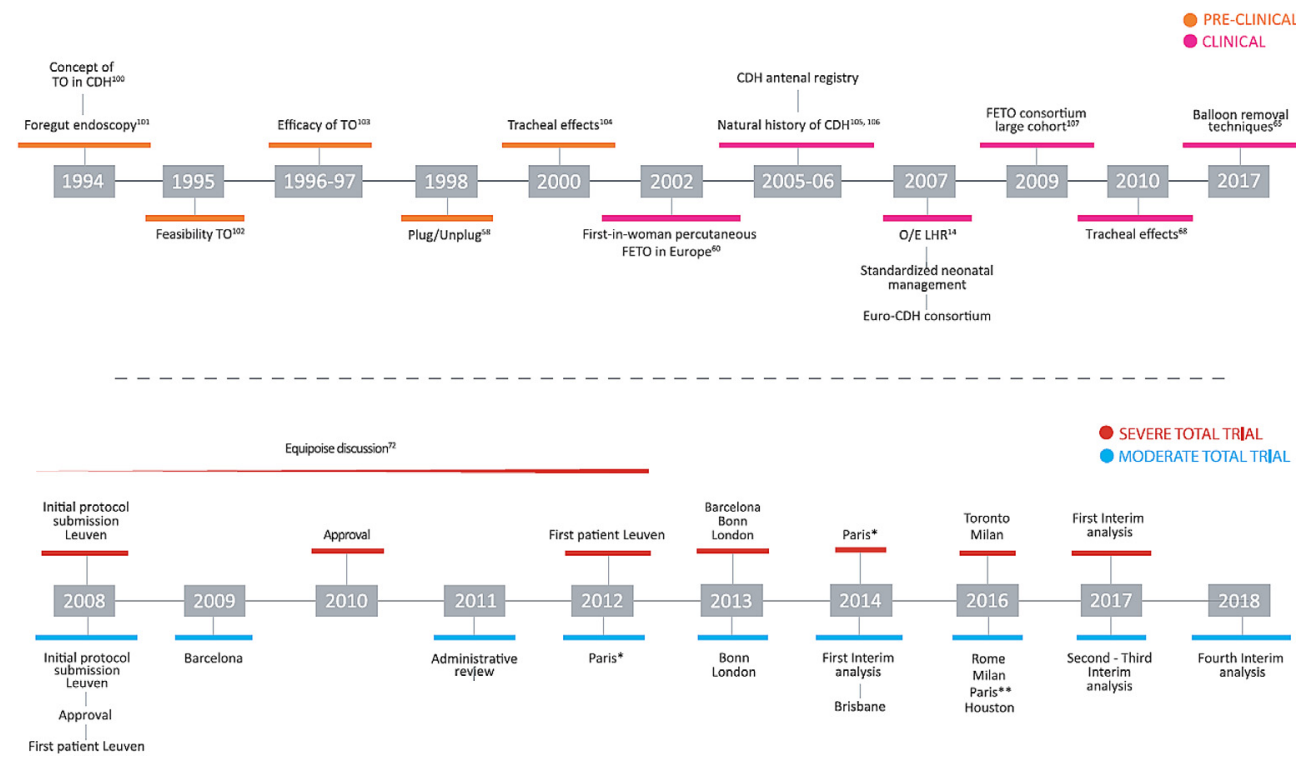

Fig. 3. Timeline of events of the making of FETO (top) and the road of the TOTAL trial (bottom); the names of the cities refer to the first patient recruited in each center. $\mathrm{CDH}$, congenital diaphragmatic hernia; *, Béclère; **, Necker. [Numbers] indicate references. Copyright UZ Leuven, Leuven, Belgium. [14,58,60,65,68,72,100-107].

for which the drug is already used postnatally. This is why we believe that the recent findings of the STRIDER trial should not be withholding us to further clinically investigate maternal sildenafil administration for $\mathrm{CDH}$. Conversely, confirmation of fetal safety becomes even more relevant and that is why we think the phase I/IIB study investigating placental transfer, maternal, and fetal safety of short-lasting sildenafil administration should be continued (EUDRACT number 2016-002619-17).

\section{Summary}

Mothers who carry a fetus with $\mathrm{CDH}$ should receive personalized counseling on the expected outcome. We recommend standardized prenatal imaging and genetic testing with microarrays. Lung size and liver herniation are good predictors of survival in LCDH; morbidity is more difficult to predict. Neonates should be managed by standardized protocols in high-volume centers. Prenatal therapy for LCDH should, according to us, only be offered within the context of the TOTAL trial; for severe RCDH, we offer the procedure clinically. Currently, medical prenatal interventions are also being investigated, which may be added to FETO or be offered as a stand-alone intervention, both improving outcome in comparison to expectant management in selected patients.

\section{PRACTICE POINTS}

- Prenatal diagnosis and individualized counseling should be at a tertiary center familiar with managing this condition and include advanced genetic testing and imaging.

- Standardized prenatal assessment and postnatal management are recommended.

- In isolated cases, prognosis is based on the side of the lesion and lung size.

- Whether liver herniation and/or position of the stomach is an independent predictor remains uncertain.

- FETO for LCDH is an investigational procedure offered within the TOTAL trial; we offer the procedure clinically for RCDH. 


\section{RESEARCH DIRECTIONS}

- Design sufficiently powered studies to develop more accurate prediction algorithms

- Investigating alternative therapies to reduce the burden or improve the outcomes of FETO.

\section{Acknowledgments}

Our research on CDH is funded by Charitable Funding of CDH-UK, the Wellcome Trust (WT101957), and the Engineering and Physical Sciences Research Council (NS/A000027/1). JD is supported by Great Ormond Street Hospital Charity fund; DB, LVDV, and JVDM are supported by Erasmus + Programme of the European Commission (2013-0040); and FMR is supported by KU Leuven (C32/17/054). This publication reflects the views only of the author, and the E.C. cannot be held responsible for any use that may be made of the information contained herein.

\section{Conflicts of interest}

None.

\section{Appendix A. Supplementary data}

Supplementary data to this article can be found online at https://doi.org/10.1016/j.bpobgyn.2018. 12.010 .

\section{References}

[1] Dolk H, Loane M, Garne E. The prevalence of congenital anomalies in Europe. Adv Exp Med Biol 2010;686:349-64.

[2] Langham Jr MR, Kays DW, Ledbetter DJ, Frentzen B, Sanford LL, Richards DS. Congenital diaphragmatic hernia. Epidemiology and outcome. Clin Perinatol 1996;23(4):671-88.

[3] Ameis D, Khoshgoo N, Keijzer R. Abnormal lung development in congenital diaphragmatic hernia. Semin Pediatr Surg 2017;26(3):123-8.

[4] Harting MT, Lally KP. The congenital diaphragmatic hernia study group registry update. Semin Fetal Neonatal Med 2014; 19(6):370-5.

[5] American Academy of Pediatrics Section on S, American Academy of Pediatrics Committee on F, Newborn Lally KP, Engle W. Postdischarge follow-up of infants with congenital diaphragmatic hernia. Pediatrics 2008;121(3):627-32.

[6] Gallot D, Boda C, Ughetto S, Perthus I, Robert-Gnansia E, Francannet C, et al. Prenatal detection and outcome of congenital diaphragmatic hernia: a French registry-based study. Ultrasound Obstet Gynecol 2007;29(3):276-83.

[7] Done E, Gucciardo L, Van Mieghem T, Devriendt K, Allegaert K, Brady P, et al. Clinically relevant discordances identified after tertiary reassessment of fetuses with isolated congenital diaphragmatic hernia. Prenat Diagn 2017;37(9):883-8.

[8] Slavotinek AM. The genetics of common disorders - congenital diaphragmatic hernia. Eur J Med Genet 2014;57(8): $418-23$.

[9] Kammoun M, Souche E, Brady P, Ding J, Cosemans N, Gratacos E, et al. Genetic profile of isolated congenital diaphragmatic hernia revealed by targeted next-generation sequencing. Prenat Diagn 2018;38(9):654-63.

[10] Kardon G, Ackerman KG, McCulley DJ, Shen Y, Wynn J, Shang L, et al. Congenital diaphragmatic hernias: from genes to mechanisms to therapies. Dis Model Mech 2017;10(8):955-70.

[11] Russo FM, Cordier AG, De Catte L, Saada J, Benachi A, Deprest J, et al. Proposal for standardized prenatal ultrasound assessment of the fetus with congenital diaphragmatic hernia by the European reference network on rare inherited and congenital anomalies (ERNICA). Prenat Diagn 2018;38(9):629-37.

[12] Metkus AP, Filly RA, Stringer MD, Harrison MR, Adzick NS. Sonographic predictors of survival in fetal diaphragmatic hernia. J Pediatr Surg 1996;31(1):148-51. discussion 51-2.

[13] Jani J, Peralta CF, Benachi A, Deprest J, Nicolaides KH. Assessment of lung area in fetuses with congenital diaphragmatic hernia. Ultrasound Obstet Gynecol 2007;30(1):72-6.

[14] Jani J, Nicolaides KH, Keller RL, Benachi A, Peralta CF, Favre R, et al. Observed to expected lung area to head circumference ratio in the prediction of survival in fetuses with isolated diaphragmatic hernia. Ultrasound Obstet Gynecol 2007;30(1): $67-71$.

[15] Hasegawa T, Kamata S, Imura K, Ishikawa S, Okuyama H, Okada A, et al. Use of lung-thorax transverse area ratio in the antenatal evaluation of lung hypoplasia in congenital diaphragmatic hernia. J Clin Ultrasound: JCU 1990;18(9):705-9.

[16] Quintero RA, Quintero LF, Chmait R, Gomez Castro L, Korst LM, Fridman M, et al. The quantitative lung index (QLI): a gestational age-independent sonographic predictor of fetal lung growth. Am J Obstet Gynecol 2011;205(6):544 e1-8. 
[17] Snoek KG, Peters NCJ, van Rosmalen J, van Heijst AFJ, Eggink AJ, Sikkel E, et al. The validity of the observed-to-expected lung-to-head ratio in congenital diaphragmatic hernia in an era of standardized neonatal treatment; a multicenter study. Prenat Diagn 2017;37(7):658-65.

[18] Ruano R, Benachi A, Joubin L, Aubry MC, Thalabard JC, Dumez Y, et al. Three-dimensional ultrasonographic assessment of fetal lung volume as prognostic factor in isolated congenital diaphragmatic hernia. BJOG 2004;111(5):423-9.

[19] Ruano R, Britto IS, Sananes N, Lee W, Sangi-Haghpeykar H, Deter RL. Growth patterns of fetal lung volumes in healthy fetuses and fetuses with isolated left-sided congenital diaphragmatic hernia. J Ultrasound Med 2016;35(6):1159-66.

[20] Benachi A, Cordier AG, Cannie M, Jani J. Advances in prenatal diagnosis of congenital diaphragmatic hernia. Semin Fetal Neonatal Med 2014;19(6):331-7.

[21] Rypens F, Metens T, Rocourt N, Sonigo P, Brunelle F, Quere MP, et al. Fetal lung volume: estimation at MR imaging-initial results. Radiology 2001;219(1):236-41.

[22] Cannie M, Jani J, Meersschaert J, Allegaert K, Done E, Marchal G, et al. Prenatal prediction of survival in isolated diaphragmatic hernia using observed to expected total fetal lung volume determined by magnetic resonance imaging based on either gestational age or fetal body volume. Ultrasound Obstet Gynecol 2008;32(5):633-9.

[23] Cannie M, Jani JC, De Keyzer F, Devlieger R, Van Schoubroeck D, Witters I, et al. Fetal body volume: use at MR imaging to quantify relative lung volume in fetuses suspected of having pulmonary hypoplasia. Radiology 2006;241(3):847-53.

[24] Nawapun K, Sandaite I, Dekoninck P, Claus F, Richter J, De Catte L, et al. Comparison of matching by body volume or gestational age for calculation of observed to expected total lung volume in fetuses with isolated congenital diaphragmatic hernia. Ultrasound Obstet Gynecol 2014;44(6):655-60.

[25] Schaible T, Busing KA, Felix JF, Hop WC, Zahn K, Wessel L, et al. Prediction of chronic lung disease, survival and need for ECMO therapy in infants with congenital diaphragmatic hernia: additional value of fetal MRI measurements? Eur J Radiol 2012;81(5):1076-82.

[26] Kilian AK, Schaible T, Hofmann V, Brade J, Neff KW, Busing KA. Congenital diaphragmatic hernia: predictive value of MRI relative lung-to-head ratio compared with MRI fetal lung volume and sonographic lung-to-head ratio. AJR Am J Roentgenol 2009;192(1):153-8.

[27] Bebbington M, Victoria T, Danzer E, Moldenhauer J, Khalek N, Johnson M, et al. Comparison of ultrasound and magnetic resonance imaging parameters in predicting survival in isolated left-sided congenital diaphragmatic hernia. Ultrasound Obstet Gynecol 2014;43(6):670-4.

[28] Albanese CT, Lopoo J, Goldstein RB, Filly RA, Feldstein VA, Calen PW, et al. Fetal liver position and perinatal outcome for congenital diaphragmatic hernia. Prenat Diagn 1998;18(11):1138-42.

[29] Lazar DA, Ruano R, Cass DL, Moise Jr KJ, Johnson A, Lee TC, et al. Defining "liver-up": does the volume of liver herniation predict outcome for fetuses with isolated left-sided congenital diaphragmatic hernia? J Pediatr Surg 2012;47(6): $1058-62$.

[30] Britto ISW, Olutoye OO, Cass DL, Zamora IJ, Lee TC, Cassady CI, et al. Quantification of liver herniation in fetuses with isolated congenital diaphragmatic hernia using two-dimensional ultrasonography. Ultrasound Obst Gyn 2015;46(2): $150-4$.

[31] Cannie M, Jani J, Chaffiotte C, Vaast P, Deruelle P, Houfflin-Debarge V, et al. Quantification of intrathoracic liver herniation by magnetic resonance imaging and prediction of postnatal survival in fetuses with congenital diaphragmatic hernia. Ultrasound Obstet Gynecol 2008;32(5):627-32.

[32] Hatch Jr EI, Kendall J, Blumhagen J. Stomach position as an in utero predictor of neonatal outcome in left-sided diaphragmatic hernia. J Pediatr Surg 1992;27(6):778-9.

[33] Dommergues M, Louis-Sylvestre C, Mandelbrot L, Oury JF, Herlicoviez M, Body G, et al. Congenital diaphragmatic hernia: can prenatal ultrasonography predict outcome? Am J Obstet Gynecol 1996;174(4):1377-81.

[34] Kitano Y, Okuyama H, Saito M, Usui N, Morikawa N, Masumoto K, et al. Re-evaluation of stomach position as a simple prognostic factor in fetal left congenital diaphragmatic hernia: a multicenter survey in Japan. Ultrasound Obstet Gynecol 2011;37(3):277-82.

[35] Cordier AG, Jani JC, Cannie MM, Rodo C, Fabietti I, Persico N, et al. Stomach position in prediction of survival in left-sided congenital diaphragmatic hernia with or without fetoscopic endoluminal tracheal occlusion. Ultrasound Obstet Gynecol 2015;46(2):155-61.

[36] Sananes N, Britto I, Akinkuotu AC, Olutoye OO, Cass DL, Sangi-Haghpeykar H, et al. Improving the prediction of neonatal outcomes in isolated left-sided congenital diaphragmatic hernia by direct and Indirect sonographic assessment of liver herniation. J Ultrasound Med 2016;35(7):1437-43.

[37] Victoria T, Bebbington MW, Danzer E, Flake AW, Johnson MP, Dinan D, et al. Use of magnetic resonance imaging in prenatal prognosis of the fetus with isolated left congenital diaphragmatic hernia. Prenat Diagn 2012;32(8):715-23.

[38] Basta AM, Lusk LA, Keller RL, Filly RA. Fetal stomach position predicts neonatal outcomes in isolated left-sided congenital diaphragmatic hernia. Fetal Diagn Ther 2016;39(4):248-55.

[39] Dillon PW, Cilley RE, Mauger D, Zachary C, Meier A. The relationship of pulmonary artery pressure and survival in congenital diaphragmatic hernia. J Pediatr Surg 2004;39(3):307-12. discussion -12.

[40] Harting MT. Congenital diaphragmatic hernia-associated pulmonary hypertension. Semin Pediatr Surg 2017;26(3): $147-53$.

[41] Russo FM, Eastwood MP, Keijzer R, Al-Maary J, Toelen J, Van Mieghem T, et al. Lung size and liver herniation predict need for extracorporeal membrane oxygenation but not pulmonary hypertension in isolated congenital diaphragmatic hernia: systematic review and meta-analysis. Ultrasound Obstet Gynecol 2017;49(6):704-13.

[42] Wong M, Reyes J, Lapidus-Krol E, Chiang M, Humpl T, Al-Faraj M, et al. Pulmonary hypertension in congenital diaphragmatic hernia patients: prognostic markers and long-term outcomes. J Pediatr Surg 2018;53(5):918-24.

[43] Fuke S, Kanzaki T, Mu J, Wasada K, Takemura M, Mitsuda N, et al. Antenatal prediction of pulmonary hypoplasia by acceleration time/ejection time ratio of fetal pulmonary arteries by Doppler blood flow velocimetry. Am J Obstet Gynecol 2003;188(1):228-33.

[44] Rizzo G, Capponi A, Chaoui R, Taddei F, Arduini D, Romanini C. Blood flow velocity waveforms from peripheral pulmonary arteries in normally grown and growth-retarded fetuses. Ultrasound Obstet Gynecol 1996;8(2):87-92. 
[45] Sokol J, Shimizu N, Bohn D, Doherty D, Ryan G, Hornberger LK. Fetal pulmonary artery diameter measurements as a predictor of morbidity in antenatally diagnosed congenital diaphragmatic hernia: a prospective study. Am J Obstet Gynecol 2006;195(2):470-7.

[46] Ruano R, Aubry MC, Barthe B, Mitanchez D, Dumez Y, Benachi A. Quantitative analysis of fetal pulmonary vasculature by 3-dimensional power Doppler ultrasonography in isolated congenital diaphragmatic hernia. Am J Obstet Gynecol 2006; 195(6):1720-8.

[47] Hernandez-Andrade E, Thuring-Jonsson A, Jansson T, Lingman G, Marsal K. Fractional moving blood volume estimation in the fetal lung using power Doppler ultrasound: a reproducibility study. Ultrasound Obstet Gynecol 2004;23(4):369-73.

[48] Cruz-Martinez R, Castanon M, Moreno-Alvarez O, Acosta-Rojas R, Martinez JM, Gratacos E. Usefulness of lung-to-head ratio and intrapulmonary arterial Doppler in predicting neonatal morbidity in fetuses with congenital diaphragmatic hernia treated with fetoscopic tracheal occlusion. Ultrasound Obstet Gynecol 2013;41(1):59-65.

[49] DeKoninck P, Jimenez J, Russo FM, Hodges R, Gratacos E, Deprest J. Assessment of pulmonary vascular reactivity to oxygen using fractional moving blood volume in fetuses with normal lung development and pulmonary hypoplasia in congenital diaphragmatic hernia. Prenat Diagn 2014;34(10):977-81.

[50] Victoria T, Danzer E, Oliver ER, Edgar JC, Iyoob S, Partridge EA, et al. Right congenital diaphragmatic hernias: is there a correlation between prenatal lung volume and postnatal survival, as in isolated left diaphragmatic hernias? Fetal Diagn Ther 2018;43(1):12-8.

[51] Schaible T, Kohl T, Reinshagen K, Brade J, Neff KW, Stressig R, et al. Right- versus left-sided congenital diaphragmatic hernia: postnatal outcome at a specialized tertiary care center. Pediatr Crit Care Med 2012;13(1):66-71.

[52] Burgos CM, Frenckner B, Luco M, Harting MT, Lally PA, Lally KP, et al. Right versus left congenital diaphragmatic hernia what's the difference? J Pediatr Surg 2017:53(1):113-7.

[53] Partridge EA, Peranteau WH, Herkert L, Rendon N, Smith H, Rintoul NE, et al. Right- versus left-sided congenital diaphragmatic hernia: a comparative outcomes analysis. J Pediatr Surg 2016;51(6):900-2.

[54] DeKoninck P, Gomez O, Sandaite I, Richter J, Nawapun K, Eerdekens A, et al. Right-sided congenital diaphragmatic hernia in a decade of fetal surgery. BJOG 2015;122(7):940-6.

[55] Deprest JA, Flake AW, Gratacos E, Ville Y, Hecher K, Nicolaides K, et al. The making of fetal surgery. Prenat Diagn 2010; 30(7):653-67.

[56] Wilson JM, DiFiore JW, Peters CA. Experimental fetal tracheal ligation prevents the pulmonary hypoplasia associated with fetal nephrectomy: possible application for congenital diaphragmatic hernia. J Pediatr Surg 1993;28(11):1433-9. discussion 9-40.

[57] Khan PA, Cloutier M, Piedboeuf B. Tracheal occlusion: a review of obstructing fetal lungs to make them grow and mature. Am J Med Genet C Semin Med Genet 2007;145C(2):125-38.

[58] Flageole H, Evrard VA, Piedboeuf B, Laberge JM, Lerut TE, Deprest JA. The plug-unplug sequence: an important step to achieve type II pneumocyte maturation in the fetal lamb model. J Pediatr Surg 1998;33(2):299-303.

[59] Davey MG, Danzer E, Schwarz U, Robinson L, Shegu S, Adzick NS, et al. Prenatal glucocorticoids improve lung morphology and partially restores surfactant mRNA expression in lambs with diaphragmatic hernia undergoing fetal tracheal occlusion. Pediatr Pulmonol 2006;41(12):1188-96.

[60] Deprest J, Gratacos E, Nicolaides KH, Group FT. Fetoscopic tracheal occlusion (FETO) for severe congenital diaphragmatic hernia: evolution of a technique and preliminary results. Ultrasound Obstet Gynecol 2004;24(2):121-6.

[61] Van der Veeken L, Russo FM, De Catte L, Gratacos E, Benachi A, Ville Y, et al. Fetoscopic endoluminal tracheal occlusion and reestablishment of fetal airways for congenital diaphragmatic hernia. Gynecol Surg 2018;15(1):9.

[62] Peralta CF, Jani JC, Van Schoubroeck D, Nicolaides KH, Deprest JA. Fetal lung volume after endoscopic tracheal occlusion in the prediction of postnatal outcome. Am J Obstet Gynecol 2008;198(1):60.e1-5.

[63] Peralta CF, Sbragia L, Bennini JR, de Fatima Assuncao Braga A, Sampaio Rousselet M, Machado Rosa IR, et al. Fetoscopic endotracheal occlusion for severe isolated diaphragmatic hernia: initial experience from a single clinic in Brazil. Fetal Diagn Ther 2011;29(1):71-7.

[64] Done E, Gratacos E, Nicolaides KH, Allegaert K, Valencia C, Castanon M, et al. Predictors of neonatal morbidity in fetuses with severe isolated congenital diaphragmatic hernia undergoing fetoscopic tracheal occlusion. Ultrasound Obstet Gynecol 2013;42(1):77-83.

[65] Jimenez JA, Eixarch E, DeKoninck P, Bennini JR, Devlieger R, Peralta CF, et al. Balloon removal after fetoscopic endoluminal tracheal occlusion for congenital diaphragmatic hernia. Am J Obstet Gynecol 2017;217(1):78 e1-e11.

[66] Jani JC, Nicolaides KH, Gratacos E, Valencia CM, Done E, Martinez JM, et al. Severe diaphragmatic hernia treated by fetal endoscopic tracheal occlusion. Ultrasound Obstet Gynecol 2009;34(3):304-10.

[67] Fayoux P, Hosana G, Devisme L, Deprest J, Jani J, Vaast P, et al. Neonatal tracheal changes following in utero fetoscopic balloon tracheal occlusion in severe congenital diaphragmatic hernia. J Pediatr Surg 2010;45(4):687-92.

[68] Deprest J, Breysem L, Gratacos E, Nicolaides K, Claus F, Debeer A, et al. Tracheal side effects following fetal endoscopic tracheal occlusion for severe congenital diaphragmatic hernia. Pediatr Radiol 2010;40(5):670-3.

[69] Deprest JA, Hyett JA, Flake AW, Nicolaides K, Gratacos E. Current controversies in prenatal diagnosis 4: should fetal surgery be done in all cases of severe diaphragmatic hernia? Prenat Diagn 2009;29(1):15-9.

[70] Nawapun K, Eastwood MP, Diaz-Cobos D, Jimenez J, Aertsen M, Gomez O, et al. In vivo evidence by magnetic resonance volumetry of a gestational age dependent response to tracheal occlusion for congenital diaphragmatic hernia. Prenat Diagn 2015;35(11):1048-56.

[71] Snoek KG, Reiss IK, Greenough A, Capolupo I, Urlesberger B, Wessel L, et al. Standardized postnatal management of infants with congenital diaphragmatic hernia in Europe: the CDH EURO consortium consensus - 2015 update. Neonatology 2016;110(1):66-74.

[72] Rodrigues HC, Deprest J, v d Berg PP. When referring physicians and researchers disagree on equipoise: the TOTAL trial experience. Prenat Diagn 2011;31(6):589-94.

[73] Deprest J, Toelen J, Debyser Z, Rodrigues C, Devlieger R, De Catte L, et al. The fetal patient - ethical aspects of fetal therapy. Facts Views Vis Obgyn 2011;3(3):221-7. 
[74] Vijfhuize S, Schaible T, Kraemer U, Cohen-Overbeek TE, Tibboel D, Reiss I. Management of pulmonary hypertension in neonates with congenital diaphragmatic hernia. Eur J Pediatr Surg 2012;22(5):374-83.

[75] Barst RJ, Ivy DD, Gaitan G, Szatmari A, Rudzinski A, Garcia AE, et al. A randomized, double-blind, placebo-controlled, dose-ranging study of oral sildenafil citrate in treatment-naive children with pulmonary arterial hypertension. Circulation 2012;125(2):324-34.

[76] Barnett CF, Machado RF. Sildenafil in the treatment of pulmonary hypertension. Vasc Health Risk Manag 2006;2(4): $411-22$.

[77] Luong C, Rey-Perra J, Vadivel A, Gilmour G, Sauve Y, Koonen D, et al. Antenatal sildenafil treatment attenuates pulmonary hypertension in experimental congenital diaphragmatic hernia. Circulation 2011;123(19):2120-31.

[78] Samangaya RA, Mires G, Shennan A, Skillern L, Howe D, McLeod A, et al. A randomised, double-blinded, placebocontrolled study of the phosphodiesterase type 5 inhibitor sildenafil for the treatment of preeclampsia. Hypertens Pregnancy 2009;28(4):369-82.

[79] Maher MA, Sayyed TM, Elkhouly N. Sildenafil citrate therapy for oligohydramnios: a randomized controlled trial. Obstet Gynecol 2017;129(4):615-20.

[80] Groom KM, Ganzevoort W, Alfirevic Z, Lim K, Papageorghiou AT, Consortium S. Clinicians should stop prescribing sildenafil for fetal growth restriction (FGR): comment from the STRIDER Consortium. Ultrasound Obstet Gynecol 2018; 52(3):295-6.

[81] Bahlmann F, Merz E, Hallermann C, Stopfkuchen H, Kramer W, Hofmann M. Congenital diaphragmatic hernia: ultrasonic measurement of fetal lungs to predict pulmonary hypoplasia. Ultrasound Obstet Gynecol 1999;14(3):162-8.

[82] Walsh DS, Hubbard AM, Olutoye OO, Howell LJ, Crombleholme TM, Flake AW, et al. Assessment of fetal lung volumes and liver herniation with magnetic resonance imaging in congenital diaphragmatic hernia. Am J Obstet Gynecol 2000;183(5): 1067-9.

[83] Kuwashima S, Nishimura G, Iimura F, Kohno T, Watanabe H, Kohno A, et al. Low-intensity fetal lungs on MRI may suggest the diagnosis of pulmonary hypoplasia. Pediatr Radiol 2001;31(9):669-72.

[84] Nawapun K, Eastwood M, Sandaite I, DeKoninck P, Claus F, Richter J, et al. Correlation of observed-to-expected total fetal lung volume with intrathoracic organ herniation on magnetic resonance imaging in fetuses with isolated left-sided congenital diaphragmatic hernia. Ultrasound Obstet Gynecol 2015;46(2):162-7.

[85] Laudy JA, de Ridder MA, Wladimiroff JW. Doppler velocimetry in branch pulmonary arteries of normal human fetuses during the second half of gestation. Pediatr Res 1997;41(6):897-901.

[86] Mitchell JM, Roberts AB, Lee A. Doppler waveforms from the pulmonary arterial system in normal fetuses and those with pulmonary hypoplasia. Ultrasound Obstet Gynecol 1998;11(3):167-72.

[87] Yoshimura S, Masuzaki H, Miura K, Muta K, Gotoh H, Ishimaru T. Diagnosis of fetal pulmonary hypoplasia by measurement of blood flow velocity waveforms of pulmonary arteries with Doppler ultrasonography. Am J Obstet Gynecol 1999;180(2 Pt 1):441-6.

[88] Mahieu-Caputo D, Aubry MC, El Sayed M, Joubin L, Thalabard JC, Dommergues M. Evaluation of fetal pulmonary vasculature by power Doppler imaging in congenital diaphragmatic hernia. J Ultrasound Med 2004;23(8):1011-7.

[89] Moreno-Alvarez O, Cruz-Martinez R, Hernandez-Andrade E, Done E, Gomez O, Deprest J, et al. Lung tissue perfusion in congenital diaphragmatic hernia and association with the lung-to-head ratio and intrapulmonary artery pulsed doppler. Ultrasound Obstet Gynecol 2010;35(5):578-82.

[90] Vuletin JF, Lim FY, Cnota J, Kline-Fath B, Salisbury S, Haberman B, et al. Prenatal pulmonary hypertension index: novel prenatal predictor of severe postnatal pulmonary artery hypertension in antenatally diagnosed congenital diaphragmatic hernia. J Pediatr Surg 2010;45(4):703-8.

[91] Laudy JA, Van Gucht M, Van Dooren MF, Wladimiroff JW, Tibboel D. Congenital diaphragmatic hernia: an evaluation of the prognostic value of the lung-to-head ratio and other prenatal parameters. Prenat Diagn 2003;23(8):634-9.

[92] Datin-Dorriere V, Rouzies S, Taupin P, Walter-Nicolet E, Benachi A, Sonigo P, et al. Prenatal prognosis in isolated congenital diaphragmatic hernia. Am J Obstet Gynecol 2008;198(1):80 e1-5.

[93] Kohl T, Gembruch U, Filsinger B, Hering R, Bruhn J, Tchatcheva K, et al. Encouraging early clinical experience with deliberately delayed temporary fetoscopic tracheal occlusion for the prenatal treatment of life-threatening right and left congenital diaphragmatic hernias. Fetal Diagn Ther 2006;21(3):314-8.

[94] Ruano R, Duarte SA, Pimenta EJ, Takashi E, da Silva MM, Tannuri U, et al. Comparison between fetal endoscopic tracheal occlusion using a 1.0-mm fetoscope and prenatal expectant management in severe congenital diaphragmatic hernia. Fetal Diagn Ther 2011;29(1):64-70.

[95] Ruano R, Yoshisaki CT, da Silva MM, Ceccon ME, Grasi MS, Tannuri U, et al. A randomized controlled trial of fetal endoscopic tracheal occlusion versus postnatal management of severe isolated congenital diaphragmatic hernia. Ultrasound Obstet Gynecol 2012;39(1):20-7.

[96] Cannie MM, Cordier AG, De Laveaucoupet J, Franchi-Abella S, Cagneaux M, Prodhomme O, et al. Liver-to-thoracic volume ratio: use at MR imaging to predict postnatal survival in fetuses with isolated congenital diaphragmatic hernia with or without prenatal tracheal occlusion. Eur Radiol 2013;23(5):1299-305.

[97] Ruano R, Peiro JL, da Silva MM, Campos JA, Carreras E, Tannuri U, et al. Early fetoscopic tracheal occlusion for extremely severe pulmonary hypoplasia in isolated congenital diaphragmatic hernia: preliminary results. Ultrasound Obstet Gynecol 2013;42(1):70-6.

[98] Persico N, Fabietti I, Ciralli F, Gentilino V, D'Ambrosi F, Boito S, et al. Fetoscopic endoluminal tracheal occlusion in fetuses with severe diaphragmatic hernia: a three-year single-center experience. Fetal Diagn Ther 2017;41(3):215-9.

[99] Belfort MA, Olutoye OO, Cass DL, Olutoye OA, Cassady CI, Mehollin-Ray AR, et al. Feasibility and outcomes of fetoscopic tracheal occlusion for severe left diaphragmatic hernia. Obstet Gynecol 2017:129(1):20-9.

[100] DiFiore JW, Fauza DO, Slavin R, Peters CA, Fackler JC, Wilson JM. Experimental fetal tracheal ligation reverses the structural and physiological effects of pulmonary hypoplasia in congenital diaphragmatic hernia. J Pediatr Surg 1994; 29(2):248-56. discussion 56-7.

[101] Luks FI, Deprest JA, Vandenberghe K, Laermans I, De Simpelaere L, Brosens IA, et al. Fetoscopy-guided fetal endoscopy in a sheep model. J Am Coll Surg 1994;178(6):609-12. 
[102] Deprest J, Evrard VA, Flageole H, Vandenberghe K, Lerut T. Experimental tracheal obstruction for congenital diaphragmatic hernia. Gynaecol Endosc 1995;4(5).

[103] Evrard VA, Verbeken EA, Vandenberghe K, Lerut T, Flageole H, Deprest JA. Endoscopic in utero tracheal plugging in the fetal lamb to treat congenital diaphragmatic hernia. J Am Assoc Gynecol Laparosc 1996;3(Suppl. 4):S11.

[104] Deprest JA, Evrard VA, Verbeken EK, Perales AJ, Delaere PR, Lerut TE, et al. Tracheal side effects of endoscopic balloon tracheal occlusion in the fetal lamb model. Eur J Obstet Gynecol Reprod Biol 2000;92(1):119-26.

[105] Jani J, Keller RL, Benachi A, Nicolaides KH, Favre R, Gratacos E, et al. Prenatal prediction of survival in isolated left-sided diaphragmatic hernia. Ultrasound Obstet Gynecol 2006;27(1):18-22.

[106] Jani J, Gratacos E, Greenough A, Piero JL, Benachi A, Harrison M, et al. Percutaneous fetal endoscopic tracheal occlusion (FETO) for severe left-sided congenital diaphragmatic hernia. Clin Obstet Gynecol 2005;48(4):910-22.

[107] Jani JC, Benachi A, Nicolaides KH, Allegaert K, Gratacos E, Mazkereth R, et al. Prenatal prediction of neonatal morbidity in survivors with congenital diaphragmatic hernia: a multicenter study. Ultrasound Obstet Gynecol 2009;33(1):64-9. 